\title{
A New Criterion for Distinguishing Yendonia Kylin and Mikamiella M.J. Wynne (Delesseriaceae, Rhodophyta)
}

\section{Olga N. Selivanova, Galina G. Zhigadlova}

Kamchatka Branch of the Pacific Geographical Institute, Far Eastern Division of the Russian Academy of Sciences, Petropavlovsk-Kamchatskii, Russia.

Email: oselivanova@mail.ru

Received October $14^{\text {th }}, 2013$; revised November $16^{\text {th }}, 2013$; accepted December $1^{\text {st }}, 2013$

Copyright (C) 2013 Olga N. Selivanova, Galina G. Zhigadlova. This is an open access article distributed under the Creative Commons Attribution License, which permits unrestricted use, distribution, and reproduction in any medium, provided the original work is properly cited.

\begin{abstract}
An additional morphological criterion is presented to distinguish vegetative samples of the genera Yendonia and Mikamiella (Delesseriaceae, Rhodophyta). The undescribed earlier feature of $Y$. crassifolia is the presence of abundant lightrefracting cells in the tissues of the blades of both fertile and vegetative plants. This feature was never observed in Mikamiella, namely, in M. ruprechtiana. Additional data amending the description of the genus Yendonia are presented.
\end{abstract}

Keywords: Rhodophyta; Delesseriaceae; Yendonia; Mikamiella; Morphological Feature

\section{Introduction}

Marine algae of the family Delesseriaceae are widespread in the Russian Pacific area and represented there by more than 20 genera [1]. There are at least 4 genera among them with similar morphology, especially in their vegetative state: Congregatocarpus Mikami, Neohypophyllum Wynne, Mikamiella Wynne and Yendonia Kylin. The main distinctive morphological features of these genera were given by Wynne [2]. The genus Neohypophyllum is distinguished from the rest genera by the absence of secondary venation in the vegetative blades. The group including Congregatocarpus and Neohypophyllum is characterized by irregular arrangement of elongate medullary cells in the midribs, while Mikamiella and Yendonia have a highly ordered arrangement of rectangular cells. Fertile samples of these algae are distinguished by localization of organs of reproduction: strictly on special proliferations in Neohypophyllum and Mikamiella and either on proliferations or scattered over the surface of ordinary blades in Congregatocarpus and Yendonia [2].

Nearly all genera are monotypic, i.e., represented by only one species except for Mikamiella that currently is considered to contain two species: Mikamiella ruprechtiana (A.D. Zinova) M.J. Wynne (= Hypophyllum ruprechtianum A.D. Zinova) and M. dentata (M.J. Wynne) M.J. Wynne (= Hypophyllum dentatum M.J. Wynne).
The only species of the genus Neohypophyllum is N. middendorffii (Ruprecht) M.J. Wynne (= Delesseria middendorffii Ruprecht) [3].

Congregatocarpus also became a monotypic genus after its re-examination by Wynne [4] who synonymized Congregatocarpus kurilensis (Ruprecht) M.J. Wynne and Congregatocarpus pacificus (Yamada) Mikami and recognized Congregatocarpus aleuticus (M.J. Wynne) Perestenko to be invalid name [4], stating that in fact the latter species belongs to the genus Laingia Kylin (L. aleutica M.J. Wynne).

The genus Yendonia previously contained three species: Yendonia crassifolia (Ruprecht) Kylin (= Delesseria crassifolia Ruprecht), Yendonia commandorensis (E.S. Sinova) A.D. Zinova (= Delesseria commandorensis E.S. Sinova) and Yendonia japonica Nagai. Now all of them are considered to be synonyms, with Yendonia crassifolia having priority $[1,3]$. Y. crassifolia resembles Congregatocarpus kurilensis in its vegetative state. But in C. kurilensis tetrasporangial sori are born on the surfaces of ordinary blades, not on special proliferations arising from the blades as in Yendonia. And vice versa, the cystocarps in Congregatocarpus are produced on special proliferations born in clusters on the surfaces of ordinary blades, while in Yendonia they are produced directly on primary blade surface [2,5]. Yendonia crassifolia is superficially most similar to Mikamiella ruprechtiana, and both spe- 
cies have polystromatic blades which produce branches from the midribs [5]. In both genera the tetrasporangia are produced on special small proliferations. But these two genera can be distinguished by the production of the sexual organs (carpogonia and spermatangia) directly on the ordinary blades in Yendonia [6] and only on special proliferations in Mikamiella [6,7]. According to Perestenko [1] proliferations bearing tetrasporangia in $\mathrm{Mi}$ kamiella are smaller than those bearing sexual organs.

From the time of publication of the original descriptions of the genera Yendonia [8] and Mikamiella [7], no new data extending their diagnoses have appeared in the literature. However, identification of the members of these genera, using available descriptions $[1,5-7,9$, etc. $]$ is sometimes complicated. In this study we tried to find more reliable and constant features for correct identification of these two taxa, represented by both fertile and vegetative samples.

\section{Materials and Methods}

Algae involved in this study were collected by the authors in the western sector of Bering Sea, at the coasts of Eastern Kamchatka and Commander Islands during several expeditions from 1986 till 2011. The studied material contained mostly subtidal samples taken from the depths $1-19 \mathrm{~m}$, in addition low intertidal and cast ashore plants were also examined. On the total we examined 53 herbarium samples of $M$. ruprechtiana (10 of them are presented in the Table 1) and 33 samples of Y. crassifolia (10 of them are presented in the Table 2).

The material was sectioned free-hand with a razor blade, placed in a drop of fresh water on a glass slide and examined using a light microscope "Olympus CX-31". The sections were studied unstained. Samples of algae were photographed using "Olympus $\mu-5010$ " and "Olympus SZ-20" digital photo cameras. Photomicrographs

Table 1. Examined samples of Mikamiella ruprechtiana.

\begin{tabular}{ccccc}
\hline Herbarium sample number & Date of collection & Location of collection & Depth & Fertility state \\
\hline $\mathbf{2 6 9 5}$ & August 20,1986 & Commander Islands, Mednyi Island, Gladkovskaya Bay & $3-4 \mathrm{~m}$ & vegetative \\
$\mathbf{1 5 3 2}$ & August 25, 1986 & Commander Islands, Bering Island, Lisinskaya Bay & $6-7 \mathrm{~m}$ & cystocarpic \\
$\mathbf{2 7 0 2}$ & September 11,1986 & Commander Islands, Bering Island, Podutyosnaya Bay & $3 \mathrm{~m}$ & vegetative \\
$\mathbf{2 6 9 1}$ & September 19,1986 & Commander Islands, Bering Island, Toporkov Islet & $1 \mathrm{~m}$ & cystocarpic \\
$\mathbf{1 5 3 0}$ & August 18, 1987 & Commander Islands, Bering Island, Cape Vkhodnoi Rif & Cast ashore & spermatangial \\
$\mathbf{1 8 1 4}$ & August 4, 1988 & Commander Islands, Bering Island, Staraya Gavan' Bay & Cast ashore & cystocarpic \\
$\mathbf{3 2 8 6}$ & July 17, 1991 & Commander Islands, Bering Island, Poludennaya Bay & $5 \mathrm{~m}$ & cystocarpic \\
$\mathbf{3 2 8 1}$ & July 4, 1992 & Commander Islands, Mednyi Island, Cape Bobrovyie Kamni & $5 \mathrm{~m}$ & spermatangial \\
$\mathbf{4 8 5 5}$ & July 27, 2011 & South- eastern Kamchatka, Avacha Gulf, Spaseniya Bay & 4 - 5 m & vegetative \\
$\mathbf{4 8 5 6}$ & July 27, 2011 & South-eastern Kamchatka, Avacha Gulf, Starichkov Island & $16 \mathrm{~m}$ & vegetative \\
\hline
\end{tabular}

Table 2. Examined samples of Yendonia crassifolia.

\begin{tabular}{ccccc}
\hline Herbarium sample number & Date of collection & Location of collection & Depth & Fertility state \\
\hline $\mathbf{1 8 9 8}$ & August 19,1988 & Bering Sea, Karaginskii Gulf, Karaginskii Island, Cape Tonos & Cast ashore & vegetative \\
$\mathbf{4 8 5 3}$ & August 19,1988 & Bering Sea, Karaginskii Gulf, Karaginskii Island, Cape Tonos & $10 \mathrm{~m}$ & cystocarpic \\
$\mathbf{2 1 0 5}$ & August 20,1988 & Bering Sea, Karaginskii Gulf, Cape Kekurnyi & $12-13 \mathrm{~m}$ & vegetative \\
$\mathbf{2 1 1 1}$ & August 20, 1988 & Bering Sea, Karaginskii Gulf, Cape Kekurnyi & $19 \mathrm{~m}$ & cystocarpic \\
$\mathbf{2 0 5 0}$ & August 21, 1988 & Bering Sea, Karaginskii Gulf, Karaginskii Island & $10 \mathrm{~m}$ & vegetative \\
$\mathbf{1 9 9 4}$ & August 22, 1988 & Bering Sea, Olyutorskii Gulf, Lavrova Bay & $10 \mathrm{~m}$ & vegetative \\
$\mathbf{1 8 9 5}$ & August 28, 1988 & Pacific Ocean, Kamchatskii Gulf, Kamenistaya Bay & $4-5 \mathrm{~m}$ & vegetative \\
$\mathbf{1 8 7 4}$ & October 7, 1988 & Bering Sea, Ozernoi Gulf, Cape Yuzhnyi-Cape Dvoinoi & Cast ashore & tetrasporic \\
$\mathbf{1 8 9 2}$ & October 7, 1988 & Bering Sea, Ozernoi Gulf, Cape Yuzhnyi-Cape Dvoinoi & Cast ashore & cystocarpic \\
$\mathbf{4 8 5 4}$ & July 27, 2011 & South-eastern Kamchatka, Avachinskii Gulf, Spaseniya Bay & $4-5 \mathrm{~m}$ & cystocarpic \\
\hline
\end{tabular}


were made using a DCM-130 digital camera.

The studied material is kept in the unregistered Herbarium of Kamchatka Branch of the Pacific Geographical Institute, Petropavlovsk-Kamchatskii, Russia.

\section{Results and Discussion}

As pointed out by different authors [1,5-7,9] M. ruprechtiana outwardly similar to $Y$. crassifolia differs from the latter in larger sizes. For instance, the maximum height of Yendonia from St. Matthew Island is about 20 $\mathrm{cm}$ while the plants of Mikamiella can reach $50 \mathrm{~cm}$ in height [10]. As a result of examination of our collections it is shown that Mikamiella (Figures 1, 2) is quite comparable in size with Yendonia (Figures 3, 4). In fact Yendonia reaches larger sizes than it was specified earlier and in some cases is even larger than Mikamiella. Thus,

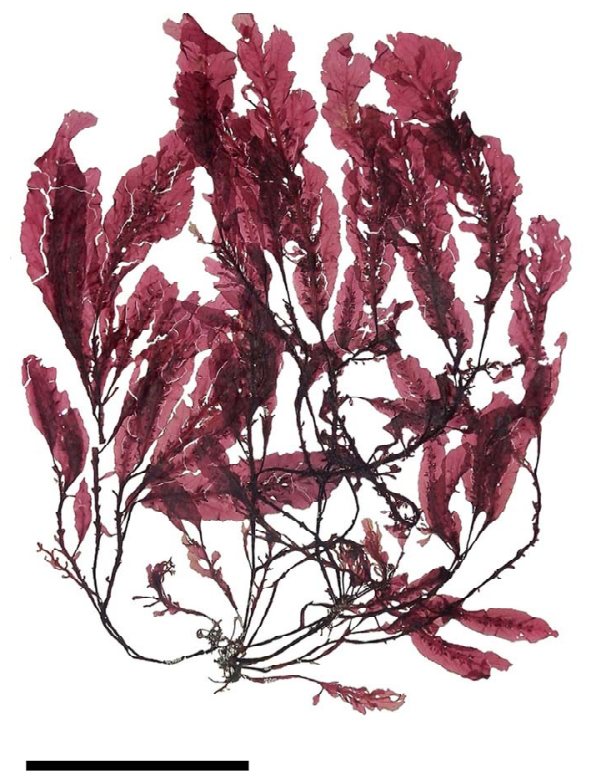

Figure 1. Mikamiella ruprechtiana, cystocarpic, voucher sample \# 1814, scale bar $9 \mathrm{~cm}$.

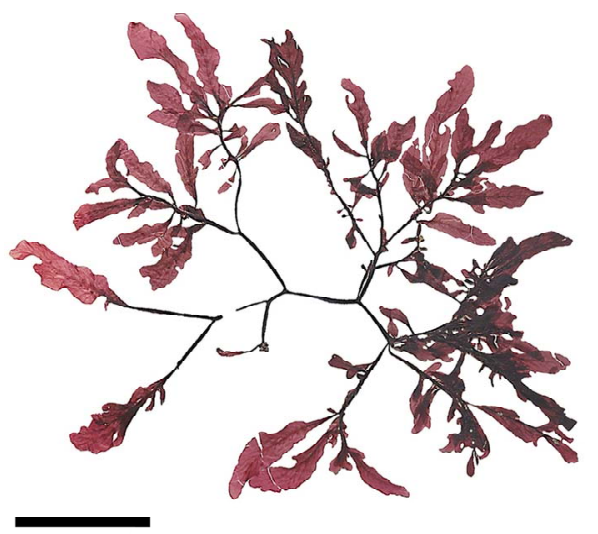

Figure 2. Mikamiella ruprechtiana, cystocarpic, voucher sample \# 3286, scale bar $8 \mathrm{~cm}$.

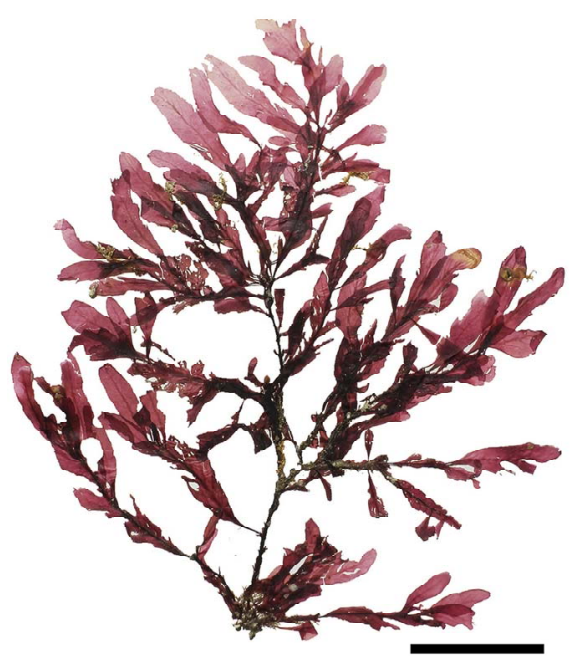

Figure 3. Yendonia crassifolia, cystocarpic, voucher sample \# 2111, scale bar $6 \mathrm{~cm}$.

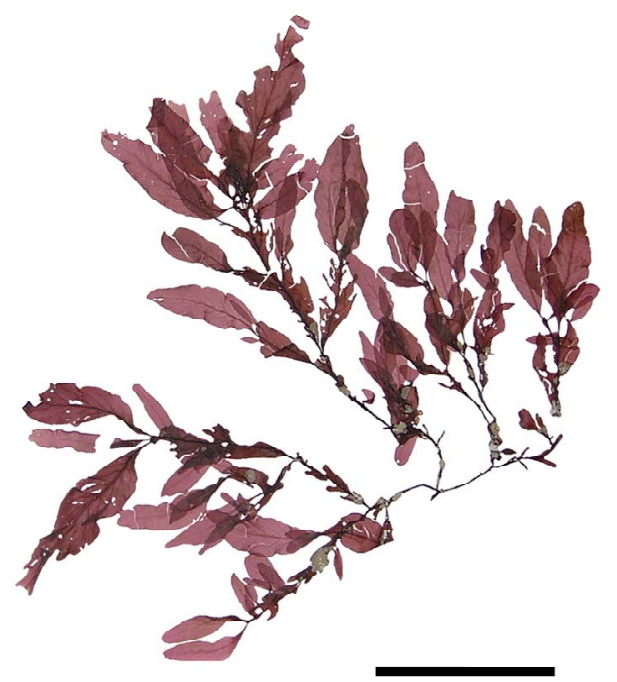

Figure 4. Yendonia crassifolia, vegetative, voucher sample \# 1994, scale bar $8 \mathrm{~cm}$.

this feature is not constant and does not help to distinguish these discussed taxa.

The anatomic structure of blades and midribs in the discussed genera are very similar as well as the structure of growing apices. Thus, the only feature for reliable distinguishing of these two genera was considered to be location of their reproductive organs. As was pointed out earlier in Yendonia, cystocarps are located on the main blades (Figure 5) while in Mikamiella they are produced on special small leaflets (Figure 6) developed along midribs and some lateral veins. In case of vegetative plants this approach cannot be applied for identification. But we have found data amending the description of the genus Yendonia that facilitate distinguishing even vegetative plants of this genus from Mikamiella samples. The essential undescribed earlier feature of $Y$. crassifolia is 
the presence of light-refracting cells developing in a considerable number in the tissues of the blades and visible from the surface view (Figures 7, 8) and in cross section (Figure 9). These cells were observed by us in all authentically defined fertile plants of Yendonia (Figure 3) as well as in vegetative plants supposed to belong to the genus Yendonia (Figure 4). This feature was never observed in Mikamiella, namely, such cells are absent in all samples of M. ruprechtiana studied by us (Figures 10, 11).

In addition to our material from the Russian Pacific

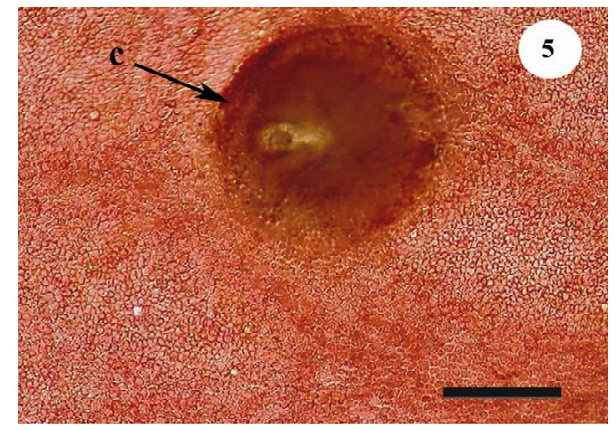

Figure 5. Yendonia crassifolia, cystocarp (c) located on the surface of the main blade near veins, voucher sample \# 2111, scale bar $200 \mu \mathrm{m}$.

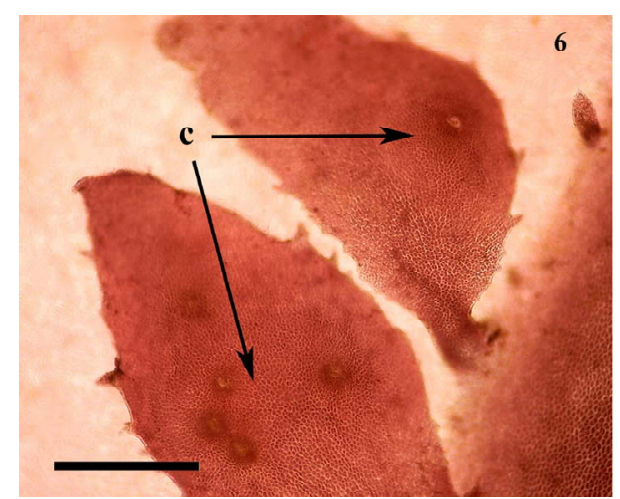

Figure 6. Mikamiella ruprechtiana, cystocarps (c) located on the surface of special leaflets, voucher sample \# 3286, scale bar $500 \mu \mathrm{m}$.



Figure 7. Yendonia crassifolia, cystocarpic, surface view of the main blade with abundant light-refracting cells (arrowheads), voucher sample \# 2111, scale bar $150 \mu \mathrm{m}$. area we also examined a sample of Yendonia from St. Paul Island (Pribilof Islands, Alaska, USA) kindly loaned to us by Professor Paul Silva (University of California, Berkeley, USA). This alga also contained light-reflecting cells (Figure 12). It permits to suppose that this feature is typical of the members of the genus Yendonia irrespective of their geographical distribution.

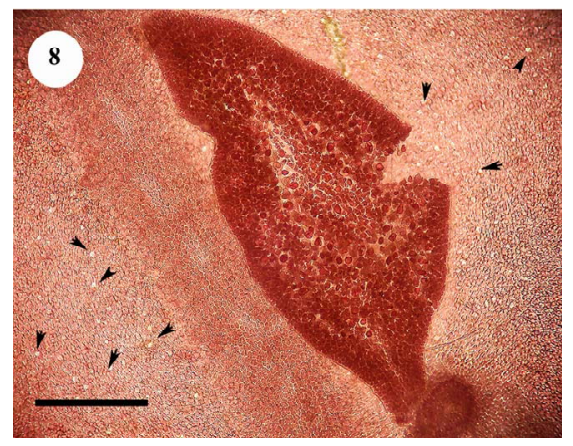

Figure 8. Yendonia crassifolia, tetrasporic, surface view of the main blade with abundant light-refracting cells (arrowheads), voucher sample \# 1874, scale bar $250 \mu \mathrm{m}$.

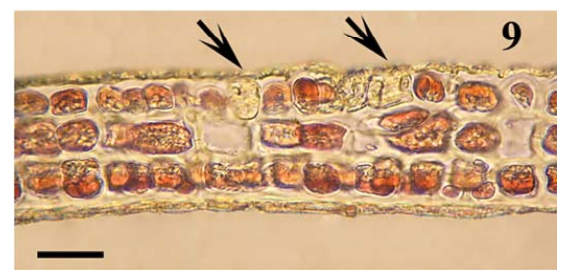

Figure 9. Yendonia crassifolia, cystocarpic, cross section of the main blade with light-refracting cells (arrows), voucher sample \# 2111, scale bar $25 \mu \mathrm{m}$.

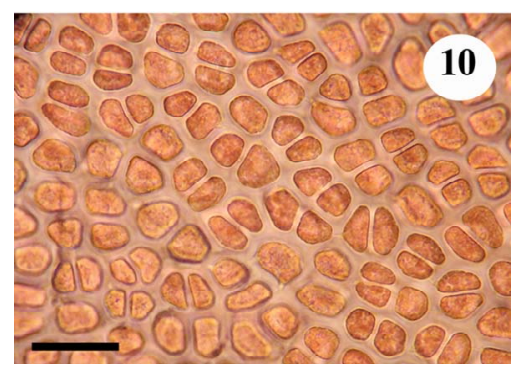

Figure 10. Mikamiella ruprechtiana, surface view of the main blade, no light-refracting cells, voucher sample \# 3286, scale bar $50 \mu \mathrm{m}$.

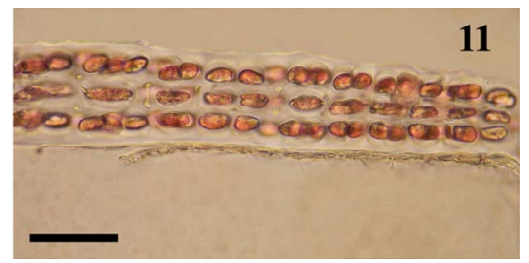

Figure 11. Mikamiella ruprechtiana, cross section of the main blade, no light-refracting cells, voucher sample \# 3286, scale bar $50 \mu \mathrm{m}$. 


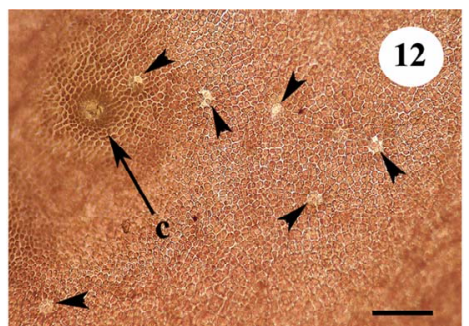

Figure 12. Yendonia crassifolia from St. Paul Island (Alaska, USA), surface view showing the presence of light reflecting cells, scale bar $100 \mu \mathrm{m}$.

As a matter of fact, we cannot explain why this diagnostic feature that helps to distinguish samples of two similar genera of the Delesseriaceae (Mikamiella and Yendonia) was hitherto overlooked by other researchers. However the presence of light-refracting (so-called glandular) cells in the tissues of the plants is also observed in some species of another morphologically related genus of this family-Phycodrys Kützing. Most abundant glandular cells are observed in $P$. vinogradovae Perestenko et Gussarova in Perestenko [11]. At the same time other species of the genus Phycodrys lack these cells, for instance, $P$. amchitkensis Wynne [6] and P. valentinae Selivanova et Zhigadlova [12]. It should be noted that this feature is unstable in some species, its variability in P. rubens (Hudson) Batters was discussed by Tokida [13]. Still it remains uncertain whether samples of $P$. rubens $f$. quercifolia (Turner) Newton in Tokida's interpretation that contained glandular cells and those devoid of them represented one and the same species.

As it is known Yendonia was placed in the Phycodrysgroup by Wynne [5,6]. We suppose that the presence of light-refracting cells is inherent for some members of the group (in our case-Yendonia) and absent in the others (in our case-Mikamiella), and this rule is more constant for Yendonia and Mikamiella than it is observed in different species within the genus Phycodrys.

It is necessary to note that despite long-term research work on the Commander Islands, we did not succeed in finding any plants of $Y$. crassifolia there, while $M$. ruprechtiana was met rather frequently. It is probable that Yendonia has disappeared from the flora of this area. It is also not excluded that records on the growth of Yendonia on the Commander Islands $[14,15]$ were based on misidentifications. The opposite situation is observed on the coasts of the eastern Kamchatka: Y. crassifolia is rather abundant in the Bering Sea, whereas M. ruprechtiana was found by us in a small number only in Avacha Gulf (south-eastern Kamchatka) (samples 4855, 4856, Table 1).

\section{Conclusion}

Thus, in our opinion, it is necessary to make the follow- ing additions in the diagnostic keys of the genera under discussion: - the presence of light-refracting cells in the blades of Yendonia (in both vegetative and fertile plants); - the absence of those in Mikamiella [16].

\section{Acknowledgements}

The authors are very grateful to Professor Michael Wynne (University of Michigan Herbarium, Ann Arbor, Michigan, USA) for critical reading of the draft manuscript. We also express our sincere gratitude to Professor Paul Silva (University of California, Berkeley, USA) for the loan of herbarium samples of Yendonia from the eastern sector of the Pacific area.

\section{REFERENCES}

[1] L. P. Perestenko, "Krasnye Vodorosli Dal'nevostochnykh Morei Rossii (Red Algae of the Far Eastern Seas of Russia)," "Olga" Publishing House, St. Petersburg, 1996 [for 1994] (In Russian).

[2] M. J. Wynne, "Records and Notes on Alaskan Marine Algae III," Contributions from the University of Michigan Herbarium, Vol. 17, 1990, pp. 335-343.

[3] M. D. Guiry and G. M. Guiry, "AlgaeBase. World-Wide Electronic Publication," National University of Ireland, Galway, 2013. http://www.algaebase.org

[4] M. J. Wynne, "Re-Examination of the Type of Delesseria kurilensis Ruprecht (Delesseriaceae, Rhodophyta)," Algae, Vol. 20, No. 4, 2005, pp. 271-278.

http://dx.doi.org/10.4490/ALGAE.2005.20.4.271

[5] M. J. Wynne, "The Current Status of Genera in the Delesseriaceae (Rhodophyta)," Botanica Marina, Vol. 26, No. 9, 1983, pp. 437-450.

http://dx.doi.org/10.1515/botm.1983.26.9.437

[6] M. J. Wynne, "Marine Algae of Amchitka Island (Aleutian Islands). I. Delesseriaceae," Syesis, Vol. 3, No. 1-2, 1970, pp. 95-144.

[7] M. J. Wynne, "Mikamiella, a New Genus of Delesseriaceae (Rhodophyta) from the North Pacific," Bulletin of the Japanese Society for Phycology, Vol. 25, 1977, pp. 395-402.

[8] H. Kylin, "Zur Nomenklatur Einiger Delesseriaceen," Fysiografiska sällskapet. Förhandlingar, Vol. 5, No. 2-3, 1935, pp. 1-5.

[9] A. D. Zinova, "Species Familiae Delesseriacearum (Rhodophyta) in Parte Septentrionali Oceani Pacifici (Representatives of the Family Delesseriaceae (Rhodophyta) in the Northern Part of the Pacific Ocean)," Novitates Systematicae Plantarum non Vascularium (News of Systematics of Spore Plants), Vol. 2, 1965, pp. 78-97 (In Russian).

[10] M. J. Wynne and J. N. Heine, "Collections of Marine Red Algae from St. Matthew and St. Lawrence Islands, the Bering Sea," Nova Hedwigia, Vol. 55, No. 1, 1992, pp. 55-97.

[11] L. P. Perestenko, "De genere Phycodrys Kütz. et Pro- 
prietatibus eius Notula (The Genus Phycodrys Kütz. and Its Characteristic Features)," Novitates Systematicae Plantarum non Vascularium (News of Systematics of Spore Plants), Vol. 20, 1983, pp. 45-51 (In Russian).

[12] O. N. Selivanova and G. G. Zhigadlova, "Phycodrys valentinae sp. nov. (Delesseriaceae, Rhodophyta) with Discussion of Other Species of the Phycodrys Genus from the North Pacific," Russian Journal of Marine Biology, Vol. 29, No. 4, 2003, pp. 206-215. http://dx.doi.org/10.1023/A:1025424607854

[13] J. Tokida, "The Marine Algae of Southern Saghalien," Memoirs of the Faculty of Fisheries Hokkaido University, Vol. 2, No. 1, 1954, pp. 1-264.

[14] E. A. Kardakova-Prejentzoffa (Prezhentsova), "The Sea- weeds of Commandor Islands," Izvestia TINRO, Vol. 14, 1938, pp. 77-108 (In Russian).

[15] S. Sinova, "The Algae of the Commander Islands," Trudy Tikhookeanskogo Komiteta (Proceedings of the Pacific Committee), Academy of Sciences of the USSR, No. 5, 1940, pp. 165-243 (In Russian).

[16] G. G. Zhigadlova, "Additional Morphological Criterion for Distinguishing Two Close taxa Mikamiella Wynne and Yendonia Kylin (Delesseriaceae, Rhodophyta)," Proceedings of International Scientific Conference Modern Problems of Algology, Rostov-on-Don, 9-13 June 2008, pp. 150-151 (In Russian). 